\title{
Parameters that influence microtensile bond testing of adhesive systems
}

\author{
Parâmetros de influência no ensaio de microtração de sistemas adesivos
}

\author{
Estevam Carlos de Oliveira LULA ${ }^{1}$ \\ Taissa Helena Martins LEITE² \\ Cláudia Maria Coelho ALVES 1 \\ Ivone Lima SANTANA' \\ Ana Maria Lima ALMEIDA' \\ José Ferreira COSTA'
}

\section{ABSTRACT}

\begin{abstract}
The aim of this study was to provide a critical review of the literature regarding factors that can interfere with microtensile test results for enamel and dentin adhesive systems. Primarily, reports in English, Spanish, or Portuguese that were published between July 1994 and September 2009 and are catalogued in MEDLINE and BBO were used. Additionally, we compiled relevant articles found in the references of these articles and dissertations and theses available in electronic databases of Brazilian universities that examined factors that can influence implementation of the microtensile test at each stage. The search strategy included searching for the following key term groups: microtensile and test; microtensile and assay; microtensile and test and parameters; microtensile and test and factors; microtensile and specimen; microtraccón and especimen. We reviewed 25 selected articles and found that they showed that even after adjustment of test parameters, changes found in the dentin could be responsible for variations observed amongst results. This influence could potentially be reduced by using the cohesive strength value of dentin adjacent to the adhesive interface as a standard for comparison, but more studies are needed to confirm whether such an approach would be reliable. Data analysis methodology should be taken into account when comparing studies.
\end{abstract}

Indexing terms: Dental materials. Dentin-bonding agents. Materials testing. Tensile strength.

\section{RESUMO}

O objetivo deste estudo foi realizar uma revisão crítica da literatura sobre os fatores que podem interferir nos resultados do teste de microtração de sistemas adesivos ao esmalte ou dentina. Foram utilizados trabalhos publicados nas bases de dados eletrônicas MEDLINE e BBO, em inglês, espanhol ou português, entre julho de 1994 e setembro de 2009, referências destes artigos, além de dissertações e teses disponíveis em bancos de dados eletrônicos de universidades brasileiras enfocando o estudo das variáveis que podem influenciar cada fase da execução do ensaio de microtração. A estratégia de busca incluiu os termos: microtração e teste; microtração e ensaio; microtensile e test e parameters; microtensile e test e factors; microtensile e specimen; microtracción e espécimen. Os 25 artigos selecionados demonstraram que mesmo após a padronização de parâmetros do ensaio, as alterações encontradas na dentina podem ser responsáveis pela variação do resultado. Uma maneira de reduzir esta influência seria utilizar os valores de resistência coesiva da dentina adjacente à interface adesiva como padrão de comparação, porém mais estudos são necessários. Aspectos relativos à análise dos dados devem ser levados em consideração quando se compara os estudos.

Termos de indexação: Materiais dentários. Adesivos dentinários. Teste de materiais. Resistência à tração.

\section{INTRODUCTION}

With the growing importance of bonding agents in clinical restoration work and the rise of new products in the dental market, it has become necessary to establish comparative parameters for the various bonding systems available. Clinical data obtained from randomised and controlled trials is the most reliable source for evaluating bonding systems ${ }^{1}$. However, it is difficult to apply this method, since longitudinal studies are needed to obtain meaningful information ${ }^{2}$. Therefore, laboratory tests have been refined such that, although they cannot predict the clinical outcome of bonding systems, they can provide useful information about how bonding systems interact with dental substrates and allow us to compare the same characteristics across different materials ${ }^{3-4}$.

Although there is no test that is able to determine all of the mechanical properties of dental materials, the microtensile strength test has grown in prominence at

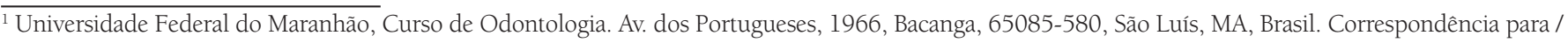
Correspondence to: ECO LULA. E-mail: <estevamcarloslula@hotmail.com>.

${ }^{2}$ Pontifícia Universidade Católica de Minas Gerais, Faculdade de Odontologia. Belo Horizonte, MG, Brasil.
} 
dental bonding research centers in the last 15 years because it is purported to overcome some of the limitations of traditional tests of shear strength and tensile strenght $t^{5-8}$.

However, despite the microtensile strength test ${ }^{7}$ representing the best stress distribution assessment available to date, the microtensile strength test results in the literature still vary widely, even when the same bonding system is compared across similar experimental conditions ${ }^{9-10}$. This variation may stem from the absence of standardization of microtensile strength testing methodology. Thus, elucidating the parameters that influence microtensile strength test results is important for correctly interpreting associated findings in the literature and obtaining a clear understanding of the research. Therefore, we conducted a critical review of the literature related to factors that might affect microtensile strength test results for enamel and dentin bonding systems.

\section{METHODS}

We searched for publications in the MEDLINE and $\mathrm{BBO}$ electronic databases in English, Spanish, and Portuguese that were published between July 1994 and September 2009. Specifically, we focused our search on studies that examined variables that might influence each phase of execution of the microtensile strength test. The following terms searches were conducted: microtensile and test; microtensile and assay; microtensile and test and parameters; microtensile and test and factors; microtensile and specimen; microtensile strength and specimen. We also used references from the articles retrieved from these databases as a research source, as well as dissertations and theses from the electronic databases available at Brazilian universities.

Two independent and blind evaluators selected studies based on their titles and abstracts, using the following inclusion criteria: studies about the effect of variation in parameters of microtensile strength assessments of adhesive resistance and stress distribution. The exclusion criterion was: comparative studies of adhesive materials or techniques. The evaluators solved disagreements through consensus.

\section{RESULTS}

Employing the search strategy described above, we identified 204 studies, of which 179 were excluded based on the exclusion criterion. The remaining 25 studies, which we included, evaluated the following parameters: 1) in relation to specimens: geometric aspects ${ }^{5-6,9,11-21}$ cutting speed ${ }^{22-23}$, cutting method ${ }^{24}$, wear-and-tear and integrity method after cutting ${ }^{23}$, storage time ${ }^{22}$, inclusion of specimens with premature failure ${ }^{24}$, imperfection during manufacture ${ }^{16}$, bonding surface area ${ }^{5,19-20,25}$, wear-and-tear method for the dentin ${ }^{26}$, form of filling and fixing ${ }^{6,15,19 ; 27}$; 2) storage time of teeth used in the assay ${ }^{28}$; 3) angle of the bond interface ${ }^{29}$; 4) incline of the dentin walls ${ }^{30}$; 5 ) variation in adhesive resistance between the teeth or within the same tooth ${ }^{31}$; 6) adhesive thickness ${ }^{30}$; 7) use of the cohesive resistance of dentin near the bonding interface as a standard of reference ${ }^{18} ; 8$ ) loading speed during the test ${ }^{19,32}$; 9) thickness of remaining dentin ${ }^{19}$; 10) imperfections in the adhesive layer ${ }^{16}$. The characteristics of the included studies are summarized in Chart 1.

\section{DISCUSSION}

Laboratory tests play a fundamental role in evaluating bonding systems as new products are being added to the market constantly ${ }^{8}$. All of the current tests used to evaluate the strength of the bond between an adhesive and dentin involve the application of force to the interface area. Therefore, it is important to understand the test mechanics and stress distribution in the interface ${ }^{3-4,33}$. The microtensile strength test was developed to overcome certain deficiencies of shear strength and tensile strengh tests 7,34 , especially the inability to use these methods to measure bond resistance with the most recent adhesive systems ${ }^{5}$. This test differs from the others in terms of the dimensions of the adhesive area used. In shear strength and tensile strengh tests, an area of approximately $4-\mathrm{mm}^{2}$ is used, whereas in the microtensile strength test, the area used is in the range of $0.5-1.5 \mathrm{~mm}^{2}$. This reduction in test area yields a number of advantages: it reduces the number of teeth needed for research; it reduces the chance of there being defects generated by fractures in the substratum; it allows for adhesive faults to be obtained in the majority of samples; and it allows adhesion to be measured in small areas $^{33-34}$.

Since its introduction in 1994, use of the test has been growing among research groups working on adhesion. Several researchers have made suggestions for how to obtain a more precise test that would optimize 
the stress distribution on the adhesive interface and allow comparison across studies. For example, adhesive resistance and stress distribution on the resin-dentin interface could be improved by: storing teeth to be used as sources of specimens for no more than 30 days in thymol or formalin28; standardizing the cutting speed, giving preference to higher speeds, so as to produce less disk oscillation and reduce specimen surface damage ${ }^{22-23}$; cutting with diamond-impregnated thread to maintain specimen integrity24; using stick-shaped specimens at least $1.5 \mathrm{~mm}$ thick in enamel bonding tests ${ }^{6}$; testing the bonding to dentin using stick-shaped ${ }^{9,14,17,23}$, dumbell ${ }^{21}$ or hourglass-shaped specimens ${ }^{7}$ with a $1-\mathrm{mm}^{2}$ adhesive area and a $1-\mathrm{mm}$ radius of curvature for the notch ${ }^{35}$; fixing specimens at both ends ${ }^{6,15,27}$; storing specimens for no more than a week in distilled water ${ }^{22}$; using a notched jig ${ }^{19}$; using sandpaper to wear dentin instead of burs ${ }^{26}$; and not using specimens with steeply inclined bond interface ${ }^{29}$.

However, even with standardization of some microtensile strength test parameters, the mechanics of laboratory tests on biological substrates with enamel and dentin remain highly variable, especially with respect to dentin's dynamic characteristic that is, its differences in mineral content, tubular density, and collagen orientation ${ }^{36}$. The range of properties related to the interaction of adhesive materials with dentin reported in the literature stems not only from different evaluation methods, but also from differences in the intrinsic structure of dentin, which is sensitive to humidity and demineralization. Adhesive resistance is higher in surface dentin than in deep dentin, and higher in normal dentin than in dentin underlying excavated caries or sclerotic dentin ${ }^{37}$.

Bovine teeth or human third molars have been used to reduce substrate variation ${ }^{4,10}$. However, there is no way to predict the level of mineralization or permeability of dentin, the depth of the preparation, and the amount of change inflicted upon dentin due to the effects of storage and other factors ${ }^{4,10,38}$. The precise intrinsic resistance of dentin varies from the enamel-dentin junction to the area near the pulp because of pre-existing defects in its structure, which function as "amplifiers" for the stress promoted by the test ${ }^{39}$.

De la Macorra and San-Nicolás ${ }^{18}$ and PerálvarezAguilera et al. ${ }^{40}$ suggest that substrate variation in testing can be minimized by using the cohesive resistance values for the dentin adjacent to the adhesive interface as a standard for comparison in microtensile strength assays. They made notches in the dentin that were $1.5 \mathrm{~mm}$ deep and wide, with an inter-notch distance of $1.5 \mathrm{~mm}$. Next, they made a resin block and obtained sticks from the notch area (to measure adhesive microtensile strength) and from the region between the notches (to measure cohesive microtensile strength). This method has enabled dentin's cohesive resistance and adhesive resistance to be evaluated at equivalent depths in the same tooth, under the same conditions of preparation. Thus, since we do not know the ideal mechanical resistance for an adhesive interface, this approach should give a sample that is at least close to the proposed substitution tissue ${ }^{18,40}$. Nevertheless, we found only two studies ${ }^{18,40}$ that evaluated how this method affected test results, limiting our ability to assess the benefits of the method relative to the conventional microtensile strength test.

There are other areas related to data analysis that may contribute to variations in microtensile strength test results and that should be taken into consideration when comparing studies ${ }^{8,23}$, such as including specimens with premature failure, including outliers (discrepant values), in the statistical treatment and the definition of the experimental unit ${ }^{8,31}$. Data means and distributions are affected when specimens with premature failure are included in the calculations. Since such specimens have negligible adhesive resistance values, their inclusion alters data normality and may preclude the use of parametric tests $^{8}$. On the other hand, if these specimens are excluded, adhesive resistance may be overestimated ${ }^{23-24}$. Similarly, including outliers can shift data patterns and affect research conclusions.

The definition of the experimental unit (i.e., teeth or sticks) can also affect the results. When multiple sticks from the same tooth are considered to be an experimental unit, a statistical flaw ensues. Sticks obtained from the same tooth cannot be considered independent samples, without increasing variation in adhesive resistance ${ }^{31}$. For this reason, each tooth should be considered a sample unit, and mean values calculated for all specimens coming from the same tooth should be analyzed.

Adhesive resistance test results do not provide a direct reflection of a property of the material itself, but rather serve as an index of the behavior of the bonding system in the particular configuration of the test. Changing any test component can lead to completely different results ${ }^{38}$. Hence, interpretation of microtensile strength test results requires careful evaluation of the methods used and the type of analysis performed. 
Chart 1. Summary of studies included in the review.

\begin{tabular}{|c|c|c|}
\hline Reference & Parameter(s) evaluated & Main results \\
\hline Sadek et al. ${ }^{5}$ & $\begin{array}{l}\text { S shape (stick, hourglass) with bonding areas of } 0.5 \\
\mathrm{~mm}^{2} \text { or } 1 \mathrm{~mm}^{2}\end{array}$ & $\begin{array}{l}\text { Notching } \rightarrow \text { Enl defects, reduced AR. } \downarrow \text { bonding area } \rightarrow \\
\downarrow A R\end{array}$ \\
\hline Meira et al. ${ }^{6}$ & $\begin{array}{l}\text { FEA in single-material, hourglass } S \text {, ranging from } \\
\text { fixation point in jig to fixation area height, } S \text { width, } \\
\text { and notch } C_{\text {rad }}\end{array}$ & $\begin{array}{l}\text { Notch } C_{\text {rad }} \text { affected AR. Fixing } S \text { on both sides } \downarrow \\
\text { concentration of stress }\end{array}$ \\
\hline Bianchi1 ${ }^{11}$ & $\begin{array}{l}\text { Hourglass-shaped S: thickness }(0.5,1,2,3,4 \mathrm{~mm}) \text {, } \\
\text { neck width (1,2 mm), filling mode (one, two sides), } \\
\text { notch shape (acute, round) }\end{array}$ & $\begin{array}{l}\uparrow \text { thickness, filling on one side or an acute notch reduced } \\
A R\end{array}$ \\
\hline Betamar et al. ${ }^{12}$ & $\begin{array}{l}\text { Hourglass-shaped S (circular, parabolic, and gentle } \\
\text { curve). FEA }\end{array}$ & $\begin{array}{l}\text { AR was greatest for circular, followed by parabolic and } \\
\text { gentle curve. StDi followed the reverse pattern }\end{array}$ \\
\hline Betamar et al. ${ }^{13}$ & S was stick, hourglass, or notched; FEA & $\begin{array}{l}\text { No difference between shapes with same bonding } \\
\text { system }\end{array}$ \\
\hline Chen et al. ${ }^{14}$ & Hourglass vs. stick S shape & $\begin{array}{l}\text { Cohesive failure in majority of conventional S; stick- } \\
\text { shape had higher AR and SD and majority of failures }\end{array}$ \\
\hline El Zohairy et al. ${ }^{15}$ & $\begin{array}{l}\text { Variation in thickness and width in the area of the } S \\
\text { fixation. FEA }\end{array}$ & $\begin{array}{l}\uparrow \text { thickness } \rightarrow \downarrow A R ; \text { no effect of width. Fixing } S \text { at both } \\
\text { ends improved } \text { StDi }\end{array}$ \\
\hline Ghassemieh $^{16}$ & $\begin{array}{l}\text { S shape (hourglass, stick, or notched) and } \\
\text { imperfections during the manufacture. FEA }\end{array}$ & $\begin{array}{l}\text { Hourglass shape yielded } \downarrow A R \text { and variance; others did } \\
\text { not differ. Adhesive bed defects affected } A R\end{array}$ \\
\hline Goracci et al. ${ }^{17}$ & $\begin{array}{l}\text { Substratum (enamel/dentin), shape (stick/hourglass), } \\
\text { and thickness }\end{array}$ & $\begin{array}{l}\uparrow A R \text { in dentin } S \text { (stick shaped or not thick). Avoid carving } \\
\text { in Enl. Hourglass } S \text { transverse area should be } \leq 1.0 \mathrm{~mm}^{2}\end{array}$ \\
\hline $\begin{array}{l}\text { de La Macorra \& San- } \\
\text { Nicolás }{ }^{18}\end{array}$ & $\begin{array}{l}\text { Use of cohesive resistance of Dn adjacent to } \\
\text { adhesive interface as a reference }\end{array}$ & No difference in adhesive vs. cohesive microtraction \\
\hline Poitevin et al. ${ }^{19}$ & $\begin{array}{l}\text { S fixation, geometry, area of adhesion, thickness of } \\
\text { remaining Dn, jig placement method, loading speed }\end{array}$ & $\begin{array}{l}\text { S orientation relative to interface influenced results and } \\
\text { failure pattern. Notched jig } \rightarrow \uparrow A R \text {. } S \text { w/o grooves and } \\
\text { W/ square transverse section } \geq 1.0 \mathrm{~mm}^{2} \text { had } \uparrow A R \text {. Dn } \\
\text { thickness affected AR contrary to placement shape and } \\
\text { loading speed }\end{array}$ \\
\hline Phrukkanon et al. ${ }^{20}$ & $\begin{array}{l}\text { Transverse area (cylindrical/rectangular) and adhesion } \\
\text { area FEA }\end{array}$ & $\begin{array}{l}\text { Adhesion areas } \leq 1.1 \mathrm{~mm}^{2} \text { had } \uparrow A R \text {. Transverse area } \\
\text { shape had a negligible influence }\end{array}$ \\
\hline Soares et al. ${ }^{21}$ & $\begin{array}{l}\text { S shape (stick, hourglass, notched) and filling } \\
\text { (posterior, superior, lateral; all) FEA }\end{array}$ & $\begin{array}{l}\text { Increase in } \mathrm{n} \text {. filled sides improved StDi. Notch-shape } \\
\text { produced more uniform StDi }\end{array}$ \\
\hline Reis et al. ${ }^{22}$ & S storage time (distilled water), cutting speed & $\begin{array}{l}\text { Optimal AR obtained with } 1 \text { wk storage, } 2.6 \mathrm{~m} / \mathrm{s} \\
\text { cutting }\end{array}$ \\
\hline Sadek $^{23}$ & Cut speed $(100,200,400$ rpm); S integrity & Dentin greater integrity than enamel, esp. at low speed \\
\hline Sadek et al. ${ }^{24}$ & $\begin{array}{l}\text { Cutting equipment (diamond disk/thread), S shape } \\
\text { (stick/hourglass), inclusion of S w/ premature failures }\end{array}$ & $\begin{array}{l}\text { Only inclusion of } S \mathrm{w} / \text { premature failures reduced } A R \\
\text { of Dn. In Enl, cutting } \mathrm{w} / \text { disk, hourglass shape, and } \\
\text { inclusion of } S \text { with failures } \rightarrow \downarrow A R\end{array}$ \\
\hline Phrukkanon et al. ${ }^{25}$ & Area of adhesion & $\begin{array}{l}\text { Area }<1.2 \mathrm{~mm}^{2} \rightarrow \uparrow A R \text { vs. } \geq 2 \mathrm{~mm}^{2} \text {, dentin-adhesive } \\
\text { failure }\end{array}$ \\
\hline Sattabanasuk et al. ${ }^{26}$ & $\begin{array}{l}\text { Dn stressing method: } 120-, 400-\text { - 1200-grain } \\
\text { sandpaper, diamond burs; carbide bur }\end{array}$ & $\begin{array}{l}\text { Diamond bur produced more compact smear level and } \\
\text { adhesion compromise than sandpaper. Carbide bur } \rightarrow \\
\text { low AR }\end{array}$ \\
\hline Poitevin et al. ${ }^{27}$ & Flat or notched jig fixation of $S$ & $\begin{array}{l}\text { Notched jig had } \uparrow A R \text {, better StDi when S fixed on both } \\
\text { ends }\end{array}$ \\
\hline Santana et al. ${ }^{28}$ & $\begin{array}{l}\text { Storage of teeth ( } 0.2 \% \text { thymol; } 10 \% \text { formalin; } 0.2 \% \\
\text { sodium azide) for } 7,30 \text { and } 180 \text { days }\end{array}$ & $\begin{array}{l}\text { Thymol and formalin had a negative effect on AR when } \\
\text { teeth were stored for } 180 \text { days }\end{array}$ \\
\hline Silva $a^{29}$ & Bond interface angle; FEA & Increase in interface incline reduced AR and stress \\
\hline Pazzinato 30 & Incline of Dn walls and Dn variation & $\begin{array}{l}\text { // vs. } \perp \text { to gravity and cervical vs. occlusal Dn no effects } \\
\text { on AR }\end{array}$ \\
\hline Loguercio et al. ${ }^{31}$ & Intra- and inter-S variation in AR & $\begin{array}{l}\text { Greater variation within tooth than between different } \\
\text { teeth }\end{array}$ \\
\hline Reis et al. ${ }^{32}$ & Loading speed $(0.1,0.5,1,2,4 \mathrm{~mm} / \mathrm{min})$ & No effect on AR \\
\hline Meira et al. ${ }^{35}$ & $\begin{array}{l}\text { S shape (stick, hourglass) and loading conditions. } \\
\text { FEA }\end{array}$ & $\begin{array}{l}\text { Stick concentrates stress outside adhesive interface and } \\
\text { cohesive fractures. Hourglass, } 1-\mathrm{mm} \mathrm{C}_{\text {rad }} \rightarrow \text { favorable } \\
\text { stress }\end{array}$ \\
\hline
\end{tabular}

Note: StDi - stress distribution; FEA - StDi by finite element analysis; $S$ - specimen; Dn - dentin; Enl - enamel; AR - adhesive resistance; $C_{\text {rad }}$ - radius of curvature, SD - standard deviation; // - parallel; $\perp$ - perpendicular; w - with; w/o - without; $\uparrow$ - increased; $\downarrow$ - decreased; $\rightarrow$ - yielded. 


\section{CONCLUSION}

Examination of the results of the studies reviewed herein led us to conclude with confidence that microtensile strength test results can be influenced by several parameters related to the specimen, the bond interface, the adhesive layer, and the substratum. Even after standardizing test parameters, variability in dentin may be responsible for variations in results. Using the cohesive resistance values of dentin adjacent to the bond interface as a standard for comparison may minimize substratum variation, although further studies are needed to confirm the validity of this approach. Other aspects such as inclusion of specimens with premature failure, inclusion of outliers, and the definition of experimental units need to be considered when comparing results across studies.

\section{REFERENCES}

1. van Meerbeek B, Perdigão J, Lambrechts $P$, Vanherle $G$. The clinical performance of adhesives. J Dent. 1998;26(1):1-20. doi: 10.1016/S0300-5712(96)00070-X.

2. Leinfelder $\mathrm{K}$. Advances in biorestorative materials: what does the future hold? J Am Dent Assoc. 2000;131(1):35-41. doi: 10.14219/jada.archive.2000.0017.

3. Eliades G. Clinical relevance of the formulation and testing of dentine bonding systems. J Dent. 1994;22(2):73-81. doi: 10.1016/0300-5712(94)90004-3

4. Fowler CS, Swartz ML, Moore BK, Rhodes BF. Influence of selected variables on adhesion testing. Dent Mater. 1992;8(4):265-9. doi: 10.1016/0109-5641(92)90097-V.

5. Sadek FT, Goracci C, Monticelli F, Ferrari M, Cardoso PEC Influência da geometria dos espécimes em dentina e esmalte no teste de microtração: análise da resistência de união e microscopia eletrônica de varredura. Rev Ibero-am Odontol Estet Dent. 2004;3(9):81-93

6. Meira JBC, Ballester RY, Lima RG, Martins de Souza R, Driemeier L. Geometrical aspects on bi-material microtensile tests. J Braz Soc of Mech Sci \& Eng. 2005;27(3):310-3. doi: 10.1590/S167858782005000300014

7. Sano H, Shono T, Sonoda H, Takatsu T, Ciucchi B, Carvalho RM, et al. Relationship between surface area for adhesion and tensile bond strength - evaluation of a micro-tensile bond test. Dent Mater. 1994;10(4):236-40.

8. Goracci C. A study on the laboratory techniques for interfacial strength testing of dental materials [PhD thesis]. Siena: University of Siena School of Dental Medicine; 2004

9. Shono $\mathrm{Y}$, Ogawa $\mathrm{T}$, Terashita $\mathrm{M}$, Carvalho RM, Pashley EL, Pashley DH. Regional measurement of resin-dentin bonding as an array. J Dent Res. 1999; 78(2):699-705. doi: $10.1177 / 00220345990780021001$

\section{Collaborators}

ECO LULA, THM LEITE, CMC ALVES, JF COSTA, IL SANTANA, AML ALMEIDA and JF COSTA selected the articles and were involved in writing the study.

\section{Acknowledgements}

This study received financial support from FAPEMA

that supported the English reviewing of this manuscript.

10. Leloup G, D'Hoore W, Bouter D, Degrange M, Vreven J. Metaanalytical review offactorsinvolved in dentin adherence. J Dent Res. 2001;80(7):1605-14. doi: 10.1177/00220345010800070301.

11. Bianchi J. Estudo sobre a resistência à microtração em função das dimensões, modo de preensão e formato do corpo-de-prova [tese]. São Paulo: Univerisdade de São Paulo; 1999.

12. Betamar N, Cardew G, van Noort R. Influence of specimen designs on the microtensile bond strength to dentin. J Adhes Dent. 2007;9(2):159-68.

13. Betamar N, Cardew G, van Noort R. The effect of variations in hourglass, specimen design on microtensile bond strength to dentin. J Adhes Dent. 2007;9(5):427-36.

14. Chen KK, Shono Y, Ogawa T, Kozono Y, Terashita M. Fracture aspects of resin-dentin bonding in non-trimming microtensile test. Dent Mater J. 2001;20(4):315-24. doi: 10.4012/ dmj.20.315.

15. El Zohairy AA, Gee AJ, Jager $N$, van Ruijven $L$, Feilzer AJ. The influence of specimen attachment and dimension on microtensile strength. J Dent Res. 2004;83(5):420-4. doi: 10.1177/154405910408300513.

16. Gassemieh E. Evaluation of sources of uncertainties in microtensile bond strength of dental adhesive system for different specimen geometries. Dent Mater. 2008;24(4):536-47. doi: 10.1016/j.dental.2007.06.022

17. Goracci C, Sadek FT, Monticelli F, Cardoso PE, Ferrari M. Influence of substrate, shape, and thickness on microtensile specimen's structural integrity and their measured bond strengths. Dent Mater. 2004;20(7):643-54. doi: 10.1016/j.dental.2003.08.009.

18. de la Macorra JC, San-Nicolás A. Method to compare $\mu$-tensile bond strength of a self-etching adhesive and $\mu$-coesive strength of adjacent dentin. Dent Mater. 2005;21(10):946-53. doi 10.1016/j.dental.2004.11.007 
19. Poitevin A, De Munck J, van Landuyt K, Coutinho E, Peumans M, Lambrechts $P$, et al. Critical analysis of the influence of different parameters on the microtensile bond strength of adhesives to dentin. J Adhes Dent. 2008;10(1):7-16.

20. Phrukkanon S, Burrow MF, Tyas MJ. The influence of crosssectional shape and surface area on the microtensile bond test. Dent Mater. 1998;14(3):212-22. doi: 10.1016/S01095641(98)00034-7.

21. Soares CJ, Soares PV, Santos-Filho PC, Armstrong SR. Microtensile specimen attachment and shape: finite element analysis. J Dent Res. 2008;87(1):89-93. doi: 10.1177/154405910808700116.

22. Reis A, Carrilho MRO, Schroeder M, Tancredo LLF, Loguercio AD. The influence of storage time and cutting speed on microtensile bond strength. J Adhes Dent. 2004;6(1):7-11.

23. Sadek FT. Influência de parâmetros metodológicos sobre o ensaio de microtração. Microscopia eletrônica de varredura e resistência de união [tese]. São Paulo: Universidade de São Paulo; 2005.

24. Sadek FT, Monticelli F, Muench A, Ferrari M, Cardoso PE. A novel method to obtain microtensile specimens minimizing cut flaws. J Biomed Mater Res B Appl Biomater. 2006;78(1):7-14. doi: 10.1002/jbm.b.30447.

25. Phrukkanon S, Burrow MF, Tyas MJ. Effect of cross-sectional surface area on bond strengths between resin and dentin. Dent Mater. 1998;14(2):120-8. doi: 10.1016/S0109-5641(98)000189.

26. Sattabanasuk V, Vachiramon V, Qian F, Armstrong SR. Resindentin bond strength as related to different surface preparation methods. J Dent. 2007;35(6):467-75. doi: 10.1016/j. jdent.2007.01.002.

27. Poitevin A, De Munck J, van Landuyt K, Coutinho E, Peumans M, Lambrechts $P$, et al. Influence of three specimen fixation modes on the micro-tensile bond strength of adhesives to dentin. Dent Mater J. 2007;26(5):694-9. doi: 10.4012/dmj.26.694.

28. Santana FR, Pereira JC, Pereira CA, Fernandes-Neto JA, Soares CJ. Influence of method and period of storage on the microtensile bond strength of indirect composite resin restorations to dentine. Braz Oral Res. 2008;22(4):352-7. doi: 10.1590/S180683242008000400012 .

29. Silva NRFA. Avaliação da resistência adesiva da interface de união em diferentes angulações empregando testes de microtração e análise dos elementos finitos [tese]. São Paulo: Universidade de São Paulo; 2003.

30. Pazzinatto FB. Influência do posicionamento do espécime na resistência adesiva à dentina e na espessura da camada de sistemas adesivos [tese]. São Paulo: Universidade de São Paulo; 2006.
31. Loguercio AD, Barroso LP, Grande RH, Reis A. Comparison of intra and intertooth resin-dentin bond strength variability. J Adhes Dent. 2005;7:151-8.

32. Reis A, de Oliveira Bauer JR, Loguercio AD. Influence of crosshead speed on resin-dentin microtensile bond strength. J Adhes Dent. 2004;6(4):275-8.

33. Pashley $\mathrm{DH}$, Sano $\mathrm{H}$, Ciucchi B, Yoshiyama M, Carvalho RM. Adhesion testing of dentin bonding agents: a review. Dent Mater. 1995;11(2):117-25. doi: 10.1016/0109-5641(95)800468.

34. Carvalho RM, Sano H, Ciucchi B, Yoshiama M, Pashley D. Determinação da resistência adesiva à dentina através de um dispositivo de micro-tração. Rev Fac Odontol Bauru. 1994;2(3):77-82.

35. Meira JB, Souza RM, Driemeier L, Ballester RY. Stress concentration in microtensile tests using uniform material. J Adhes Dent. 2004;6(4):267-73.

36. Hosoya Y, Kawada E, Liu J, Oda Y, Marshall Jr GW. Micro-tensile strength of sound primary second molar dentin. J Mater Sci. 2005;40(23):6181-6. doi: 10.1007/s10853-005-3159-1

37. Marshall GW Jr, Marshall SJ, Kinney JH, Balooch M. The dentin substrate: structure and properties related to bonding. J Dent. 1997;25(6):441-58. doi: 10.1016/\$0300-5712(96)00065-6.

38. De Munck J, van Laduyt K, Peumans M, Poitevin A, Lambrechts P, Braem $M$, et al. A critical review of the durability of adhesion to tooth tissue: methods and results. J Dent Res. 2005;84(2):11832. doi: $10.1177 / 154405910508400204$.

39. Staninec M, Marshall GW, Hilton J, Pashley DH, Gansky S, Marshall SJ, et al. Ultimate tensile strength of dentin: evidence for a damage mechanics approach to dentin failure. J Biomed Mater Res (Appl Biomater). 2002;63(3):342-5. doi: 10.1002/ jbm. 10230.

40. Perálvarez-Aguilera F, Escribano-Mediavilla N, de la MacorraGarcia JC. Resistência mecánica de la interfase y de la dentina adyacente: estúdio comparativo de microtracción. RCOE 2001;6(6):621-7. 